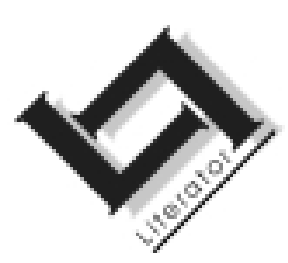

\title{
Mitisiteit as basis vir vergelykende literatuurstudie, met verwysing na waterslangsimboliek
}

\author{
Jean Lombard \\ Afdeling Afrikaans \\ Universiteit van Namibië \\ WINDHOEK \\ E-pos: JeanLombard3@aol.com
}

\section{Abstract}

Mythicity as basis for comparative literature, with reference to water snake symbolism

Mythicity can be defined as the deliberate intention of probing the numinous dimensions of human existence by means of literature, i.e. mainly narrative forms. In this article the water snake is chosen as prominent archetypal symbol in order to investigate the functioning of mythicity. The water snake is an important symbol in the Southern African context, with its origins in Khoesan ritual and mythology. Recently several stories about water snakes and related mythological creatures have been published in Afrikaans novels and short stories. The water snake has also assimilated influences, inter alia from European, Asian and other African cultures. In this article the potential of mythicity is specifically investigated insofar as it can be utilised as basis for comparative literature. For this purpose the numinous dimensions of a mythic story are treated as equally important as the narrative dimensions. This dialectical balance is therefore used as the main criterion for the comparison of mythic texts. Other related aspects are discussed, namely the importance of the historical context, Jung's theory of archetypes and the unconscious, and the role of interpretational devices such as metaphor, metonymy, symbolism and allegory. If the balance between numinosity and narrativity is not maintained, the mythic potential of a text is usually reduced. When writers succeed in utilising mythicity as an "open", dynamic interpretational process, mythic relevance can still be guaranteed within a present-day, postmodern context. 


\section{Opsomming}

Mitisiteit as basis vir vergelykende literatuurstudie, met verwysing na waterslangsimboliek

Mitisiteit kan gedefinieer word as die doelbewuste intensie om die numineuse dimensies van die menslike bestaan deur middel van literatuur - hoofsaaklik narratiewe vorme - te peil. Vir die doel van hierdie artikel is die waterslang as prominente argetipiese simbool gekies ten einde die funksionering van mitisiteit te ondersoek. Dit is 'n belangrike simbool binne die Suider-Afrikaanse konteks, met sy oorspronge in Khoesaan-rituele en die mitologie. Relatief onlangs het talle verhale oor waterslange en verwante mitologiese wesens in die Afrikaanse prosa verskyn. Die waterslang het ook invloede van onder meer die Europese, Asiatiese en ander Afrikakulture geassimileer. Die potensiaal van mitisiteit word in hierdie artikel spesifiek ondersoek vir sover dit benut kan word as basis vir vergelykende literatuurstudie. Vir dié doel is die numineuse dimensies van die mitiese verhaal net so belangrik as die narratiewe dimensies. Hierdie dialektiese balans word daarom aangewend as die hoofkriterium vir die vergelyking van mitiese tekste. Ander verwante aspekte word bespreek, naamlik die belangrikheid van die historiese konteks, Jung se teorie oor argetipes en die onbewuste, en die rol van interpretasiemeganismes soos metafoor, metonimie, simboliek en allegorie. Indien die balans tussen numinositeit en narratiwiteit nie gehandhaaf word nie, word die mitiese potensiaal van 'n teks meestal verskraal. Wanneer skrywers wel daarin slaag om mitisiteit as 'n "oop", dinamiese interpretatiewe proses te ontgin, kan mitiese relevansie binne die huidige, postmoderne konteks steeds gewaarborg word.

\section{Inleiding}

Die verwerking van motiewe uit Afrikamitologieë is 'n opvallende en belangrike ontwikkeling binne die omvattende terrein van die SuiderAfrikaanse letterkunde, ook in resente Afrikaanse prosa. Die buitengewoon groot waterslang, met die wonderbaarlike blink steen op die voorkop, is 'n spesifieke mitologiese verskynsel wat uitsonderlike aandag in alle Suider-Afrikaanse letterkundes geniet. In die Afrikaanse letterkunde speel veral die waterslang van die Oranjerivier (of Groot Gariep), met sy oorspronge in die Khoesaan-mitologie, 'n baie belangrike rol. Bekende skrywers wie se werk as voorbeeld kan dien, is onder andere André P. Brink, Thomas Deacon, Antjie Krog, Elias P. Nel, Wilma Stockenström, Piet van Rooyen en George Weideman.

Hoewel daar in die loop van die artikel 'n hele aantal verwysings na voorbeelde van waterslangsimboliek voorkom - spesifiek uit die 
Afrikaanse prosa - dien hierdie verwysings slegs as toeligting ten einde vrae van teoretiese aard te beantwoord, naamlik vrae aangaande die redes vir en relevansie van sodanige mitiese verwerkings in literatuur. Die artikel beoog om die funksionering van die mitiese intensie by skrywers uit enige taalgebied na te gaan na aanleiding van die begrip "mitisiteit". 'n Vraag wat in hierdie verband ter sake is, maar waarop hier nie ingegaan kan word nie, is byvoorbeeld in watter mate die gewildheid van boeke soos The lord of the rings deur J.R.R. Tolkien en die befaamde Harry Potter-reeks van J.K. Rowling met die verskynsel van mitisiteit te make het al dan nie.

Verskeie samehangende aspekte van mitisiteit word ondersoek. Daar word gewys op die belangrikheid van die balans tussen narratiewe en numineuse dimensies in die verwerking van die mitologiese gegewe. Die argetipiese oorspronge van die mitiese intensie in die onbewuste word nagegaan, asook die wisselwerking tussen mite en konteks (die rol van geskiedenis en ideologie). Voorts word aangetoon hoe die literêre procédés metafoor, metonimie, simboliek en allegorie funksioneer ten opsigte van die herinterpretasie- en representasieproses van ou mitologiese simbole binne 'n nuwe skrywers- en leserskonteks. Ten slotte word gekyk na literêre kriteria ten einde die geslaagdheid van mitisiteit in verskillende tekste en kontekste te beoordeel. ${ }^{1}$ Sodanige evaluering geskied na aanleiding van die onderlinge vergelyking van tekste met 'n gemeenskaplike mitiese inslag, byvoorbeeld slang- en/of watersimboliek. In die proses word betoog dat 'n fyn balans tussen narratiewe en numineuse aspekte die verskraling van mitisiteit teenwerk en die suksesvolle verwerking van ou mitologiese simbole bevorder. Aan die hand van waterslangsimboliek in Afrikaanse tekste word mitisiteit dus as basis vir vergelykende literatuurstudie ondersoek.

Dit is opvallend dat vele mitologiese motiewe in die huidige tyd opnuut binne Suider-Afrikaanse konteks ontgin word. Die vraag wat ontstaan, is naamlik waarom mitologiese verskynsels soos die waterslang juis nou - binne 'n postmodernistiese konteks - soveel aandag kry? Vanwaar die hernude aandag aan 'n simbool wat sy oorspronge in die haas verdwene gebruike van die religieuse belewing van onder meer "primitiewe" Afrika het? In hierdie artikel

$1 \quad$ Vir ' $n$ vollediger uiteensetting van die teoretiese aspekte soos weergegee in hierdie artikel, sien Hoofstuk 2 van Lombard (1999). 
word 'n saak daarvoor uitgemaak dat die antwoorde op hierdie vrae direk te make het met die verskynsel van mitisiteit. Mitisiteit kan kortliks omskryf word as die ingesteldheid of bewussyn wat gepaardgaan met die doelbewuste intensie om die numineuse deur middel van literatuur - veral narratiewe vorme - te peil. Die numineuse verwys na die onuitspreeklike of onnaspeurbare dimensies van die menslike bestaan, wat dus verband hou met religieuse belewings. Hierdie omskrywing sluit in hoofsaak aan by beskouings van Eric Gould, soos uiteengesit in sy Mythical intentions in modern literature (1981). In die onderafdelings wat volg, word tot op groot hoogte gesteun op insigte van Gould en sy verwerking van die beskouings van bekende teoretici soos Barthes, De Saussure, Jung, Lacan en Ricoeur.

Die artikel word in drie hoofafdelings ingedeel. Daar word kortliks ingegaan op die agtergronde van die waterslangsimboliek (afdeling 2). In die kerngedeelte wat volg, word gefokus op die verskillende verbandhoudende aspekte van mitisiteit (afdeling 3, onderverdeel in 4 subafdelings). Op die basis van hierdie hoofsaaklik teoretiese uiteensetting word 'n stap verder gegaan, naamlik die uiteensetting van kriteria vir die suksesvolle aanwending van die mitisiteitsbegrip in vergelykende literatuurstudie (afdeling 4). Die betoog word afgesluit met 'n kort samevatting (afdeling 5).

Hierdie artikel is die eerste van twee wat handel oor die verwerking van waterslangsimboliek in literêre vorm. In die tweede artikel word gefokus op die teksontleding van 'n aantal geselekteerde Afrikaanse waterslangverhale, ten einde te illustreer hoe mitisiteit binne die konkrete teks funksioneer. Afgesien van die moontlikhede wat die verwerking van mitologiese motiewe vir die vergelyking van verhale bied, sal blyk dat die benutting van die mitiese potensiaal van 'n gegewe soos die waterslang 'n vry ingewikkelde proses is wat helaas nie altyd na verwagting verwerklik word nie.

\section{Oorspronge en invloede met betrekking tot waterslangsimboliek}

Die oorspronge van die waterslang, as belangrike mitologiese simbool spesifiek binne Suider-Afrikaanse konteks, gaan terug tot die reënmaking- en inisiasierituele van die Khoesaan. Ten opsigte van die reënmakingsritueel sou daar definitiewe assosiatiewe verbande bestaan tussen byvoorbeeld die volgende: die transdans van die sjamaan, mistieke onderwater-ervarings en die identifikasie met diere wat oor besondere potensie beskik, soos die magtige 
eland, die mitologiese reënbul en die waterslang (vgl. LewisWilliams \& Dowson, 1989:94). By inisiasierituele van veral jongmeisies speel die waterslang 'n baie belangrike rol. Daar is geglo dat enige persoon wat hom- of haarself in 'n oorgangsfase bevind, oor besondere kragte beskik. Die sterk magte van die natuur, soos gesimboliseer deur onder meer die waterslang, moet steeds in harmonie gebring word met die toenemende menslike potensie, wat aanleiding gee tot allerlei rituele gebruike rondom die waterslang en verwante simboliese verskynsels (Hoff, 1995:38).

Die invloede wat op die verwerking van waterslangsimboliek in byvoorbeeld die Afrikaanse letterkunde 'n rol gespeel het, is nie net beperk tot Suider-Afrikaanse kontekste nie. Ook in die res van die Afrika-kontinent wil dit voorkom asof bykans elke belangrike meer of rivier oor 'n watergod beskik, dikwels in die vorm van 'n slang of verwante dier. Europese invloede blyk duidelik uit die reste van vele sprokies, byvoorbeeld dié van die broers Grimm (vgl. Schmidt, 1982:3). Invloede uit Asië hou verband met verskynsels soos die slangsteen, wat in die voorkop van 'n slang aangetref sou word en oor besondere genesende kragte beskik. Dié soort stene is in die tyd van die Oos-Indiese Kompanjie deur slawe aan die Kaap aan blankes verkoop (Grobbelaar, 1994:104).

Onderliggend aan dergelike invloede uit Asië is die omvattende Indiese mitologie, met talle magiese stene en slange. Dergelike motiewe, dikwels gekombineer met watersimboliek, kom algemeen in die bekende wêreldmitologieë voor, waaronder die Griekse, Noorse, Asteekse, Indiaanse en inheemse Australiese mitologieë. Mitologiese verhale uit die ou Sumeriese en Babiloniese beskawings vorm op hulle beurt die basis van die groot aantal verwysings na mitologiese slange en waterdiere in die Bybel. Sommige van die interessantste perspektiewe op mitisiteit, spesifiek binne die Afrikaanse prosa, kom na vore in die intertekstuele spanning tussen tradisionele waterslangverhale enersyds en die Christelike tradisie andersyds.

Die assosiasies rondom die slang- en watersimboliek, soos byvoorbeeld in mitologie-ensiklopedieë nagegaan kan word, is oneindig. Daarby kan nog gevoeg word die groot verskeidenheid variante en verskyningsvorme van die waterslang, waaronder die kosmiese Ourobouros en die Bybelse Leviatan, maar ook SuiderAfrikaans georiënteerde wesens soos die dassie-adder, basilisk of tokkelossie. Binne die orale tradisie word daar ook voortdurend uitgebrei op bestaande ervarings en verhale rondom hierdie verskynsels. Bloot op grond van die kwantitatiewe hoeveelheid 
assosiasies rondom 'n verskynsel soos die waterslang bestaan daar tallose moontlikhede vir intertekstuele vergelyking. Dit is egter nie in die eerste plek waaroor mitisiteit gaan nie, naamlik om soveel as moontlik assosiasies rondom 'n bepaalde mitologiese simbool op te bou of met mekaar te vergelyk nie. Dit gaan veel eerder oor 'n definitiewe mitiese ingesteldheid of intensie ten opsigte van die mitologiese gegewe; vandaar die onderskeid "mitologies" teenoor "mities", waarop later in meer detail ingegaan sal word.

\section{Aspekte van mitisiteit}

Een van die belangrikste voorwaardes vir 'n mitiese ingesteldheid is die doelbewuste intensie 2 by die skrywer om die numineuse te peil. Gould (1981:178) omskryf numinositeit as "the intention especially to confront the unanswerable". Die mite uit vervloë tye word opnuut relevant gemaak deur dit binne die moderne konteks van resente en relevante vraagstellings te plaas. Die geslaagdheid van mitisiteit al dan nie word in groot mate bepaal deur die volgehoue numineuse vraagstelling: "For the numinous to remain a useful term, it must remain problematic" (Gould, 1981:260). Paradoks en ironie hang dus ten nouste saam met die mitiese instelling, aangesien 'n doel of intensie nagestreef word wat by voorbaat nie werklik bereikbaar is nie, omdat taal en werklikheid nie saamval nie. Die paradoks van die menslike bestaan is daarin geleë dat juis die ontoereikendheid van talige pogings tot singewing (soos deur middel van die mite), die mens voortdurend dwing om - meestal deur middel van taal - dié ontoereikendheid te probeer oorkom; meer nog, die ontoereikendheid as sodanig steeds beter te omskryf en te begryp.

\subsection{Die fyn balans tussen die narratiewe en numineuse dimensies van mitisiteit}

In die oneindige hoeveelheid definisies van "mite", soos byvoorbeeld in ensiklopedieë en woordeboeke nagegaan kan word, is daar twee aspekte wat deurlopend in samehang met mekaar genoem word, naamlik die verhalende of narratiewe aard van die mite, asook die religieuse of numineuse dimensie daarvan. In hierdie ondersoek word die term "numineuse" verkies, omdat dit wyer gaan as net 'n bepaalde religieuse duiding. Sonder deeglike inagneming van

2 Hier kan daar nie op die kompleksiteit van die intensiebegrip ingegaan word nie, byvoorbeeld soos deur die New Critics aangedui as intentional fallacy. 
hierdie tweede aspek word die mite byvoorbeeld gesien as bloot ' $n$ "valse waarheid" of "fabel, storie sonder grond" (HAT, 1994:670).

Ten einde die dubbele werking van mitisiteit, as sowel narratiewe én numineuse verskynsel, goed te begryp, moet dit volgens Gould (1981:7) in die eerste plek herlei word tot die linguistiese basis van die mite, naamlik mite as taal, ter onderskeiding van byvoorbeeld mite as ritueel. Die willekeurige verhouding tussen die betekenaar (signifier) en betekende (signified), as een van die belangrikste linguistiese insigte van Ferdinand de Saussure en ander ná hom, lê ten grondslag aan die ontstaan van die mite en die voortsetting daarvan in die vorm van mitisiteit. Die algemene verskynsel dat gebeure (enersyds) en ons talige pogings om hulle sin te gee (andersyds) nie saamval nie, gee onder meer aanleiding tot die ontstaan van mites. Een van die basiese uitgangspunte van Gould (1981:6) se ondersoek na mitisiteit is naamlik: "If there is one persistent belief in this study, it is that there can be no myth without an ontological gap between event and meaning." Taal illustreer die gaping tussen dit wat met die mens gebeur, en pogings om sin of betekenis daaraan te gee. Die gaping word nooit oorbrug nie, maar dit is juis ook primêr deur middel van taal dat sin of betekenis aan die menslike bestaan gegee word. Die voortdurende omgaan met hierdie paradoks waarborg die kontinuering van die mitiese denkwyse.

Op die basis van 'n gemeenskaplike strewe om die gaping tussen gebeure en singewing te oorbrug, kan mite en literatuur binne 'n kontinuum geplaas word. In aansluiting by Gould se formulering van die ontologiese gaping tussen gebeurtenis en singewing (laasgenoemde in die vorm van taal, mite en verhaal) kan die afleiding gemaak word dat stories - oftewel narratiwiteit - 'n wesenlike substraat van die menslike bestaan uitmaak. Homo sapiens is inderdaad ook homo narrans (vgl. Dégh, 1977:386).

Die numineuse is in 'n sekere sin veel moeiliker te omskryf as die narratiewe, aangesien dit gaan om die "heilige", die "onuitspreeklike" - dit wat bo die menslike rede uitgaan. Soos in die geval van die vertel van verhale is die oorsprong van die drang om die onverklaarbare te benader, geleë in die wesenlike aard van taal. Om nogeens by Gould (1981:195) se sienings aan te sluit: “... wherever the gap - as it always does in the intent to give meaning form - the sense of the numinous is potentially available". Juis wanneer dit gaan oor 'n spreke oor God, word die gaping tussen realiteit en ervaring soveel meer prominent. Vandaar die insig in hedendaagse 
teologiese diskussies dat daar oor God slegs in terme van metafore en simbole gepraat kan word (vgl. McFague, 1982).

Soos by narratiwiteit kom die paradoks ook in die hantering van die numineuse na vore. Hoewel die mens skynbaar weet dat hy in sy numineuse vraagstellings geen definitiewe antwoorde gaan kry nie, wil dit voorkom asof hy gewoon nie anders kán as om steeds die pogings aan te wend nie. Die literêre taaluiting, wat 'n vorm van bewustelike intensie verteenwoordig, het steeds ten doel om die breuk tussen gebeurtenis en singewing te oorbrug - soveel te meer die verhaal met doelbewuste mitiese of religieuse intensies.

Wanneer J.S. Krüger in sy boek Along edges (1995:34) oor die oorspronge van religie skryf, doen hy dit op 'n manier wat die onlosmaaklike relasie van kuns en numinositeit beklemtoon: "Awe at the immensities and complexities of the world without and the world within is the genesis of religion, as it is of science and art." Vir Krüger (1995:3) gaan dit om religiositeit as 'n basiese menslike ingesteldheid:

By 'religion' I understand in a general sense the dream and the effort found in all cultures to look at our ordinary world sub specie aeternitatis (vry vertaal: "in die lig van die ewigheid" $\mathrm{JL}$ ), in the widest horizon possible. The topics usually associated with religion (afterlife; God or gods; myth; ritual) make sense only in the light of that idea."

So gesien, is dit moontlik om religieuse belewing as universeel te dui, sodat daar - in ooreenstemming met die tipering homo narrans - ook sprake kan wees van homo religiosus (Krüger, 1995:59).

Vir die kritiese leser van mitiese tekste word die spanning binne die verhaal volgehou in die subtiele wisselwerking tussen narratiewe en numineuse dimensies. Dié spanning of balans hou verband met talle ander dinamiese verhoudings binne die teks: tussen mite en verhaal, tussen mondelinge en skriftelike ekspressie, tussen mite en ideologie. Die versteuring van die balans tussen die narratiewe en die numineuse hou direk verband met die rol van historiese faktore, soos bepaal deur die spesifieke kontekste waarmee die teks in gesprek tree. Voordat daar nader ingegaan word op die verhouding mite en konteks, word die argetipiese oorspronge van mitologiese simboliek vervolgens aan die orde gestel. 


\subsection{Argetipes en die onbewuste as oorsprong van die mite}

Dit is veral Jung se teorieë oor argetipes, as kerndimensies van die menslike onbewuste, wat van belang is vir die bestudering van die verhouding tussen mite en literatuur. Argetipes, oftewel "primordial images" (Gould, 1981:16), verteenwoordig by uitstek die onbewuste as oorsprong van die mite. In bewuste, talige vorm vind argetipiese beelde neerslag in simbole, wat op hul beurt weer die duidelikste tot uitdrukking kom in die taalgebruik van mite en literatuur. Mede as gevolg van die wye verspreiding daarvan in die wêreldmitologieë, kan die waterslang as so 'n argetipiese simbool beskou word.

Volgens Gould het die paradoksale strewe onderliggend aan mitisiteit, naamlik om deur middel van taal voortdurend die breuk tussen gebeurtenis en betekenis te vul, sy eintlike oorsprong in die onbewuste. Die "sense of the mythic" (Gould, 1981:44) kan herken word aan "its function of endowing symbols with archetypal qualities". Die doel van die interpretasie van veral mitiese tekste is in die eerste instansie om vas te stel hoe die oordrag van die argetipiese (vanuit die onbewuste) na die simboliese (in die teks) bewerkstellig word.

Al hierdie prosesse vind plaas, volgens Jung, binne die sfeer van die religieuse of numineuse. Soos wat die onbewuste aanleiding gee tot die ontstaan van mites, so kan die onbewuste volgens Jung ook gesien word as oorsprong van die mens se religieuse belewing. Krüger (1995:29-30) skryf in hierdie verband: "This was the point made by Jung: if it is only through the psyche that God acts upon us, then God and psyche are practically indistinguishable."

Ondanks die wye aandag wat Jung se teorieë in veral psigologiese en literêre kringe geniet, behou hulle steeds 'n mate van kontroversialiteit, mede as gevolg van Jung se eie, definitiewe standpunt dat argetipes, as deel van die onbewuste, nooit volledig op bewuste wyse geken kan word nie. Volgens Robert A. Segal (1984:245) is dit die hoofrede waarom Jung se teorieë altyd iets van "a mystical, antiintellectual aspect" sal behou. Segal (1984:264) wil wel 'n saak daarvoor uitmaak dat die mite in verhalende vorm die naaste daaraan kom om die bestaan van argetipes te verifieer.

In sy poging om die talige werking van die argetipe in minder mistifiserende terme as Jung te beskryf, beklemtoon Gould (1981: 33) die voortdurende verband tussen die argetipe en interpretasie: "the archetype is but a representation of experience resulting itself from the quite distinct intent to make an interpretation of the world". 
Hierdie "interpretation of the world" bring ons terug by Gould (1981:42) se basiese uitgangspunt aangaande mitisiteit: "Language embodies the semiotic gap which determines all interpretation, and myth is that function of language which intentionally tries to close that gap." Juis die "semiotic gap" gee aanleiding tot die feit dat die aard van sowel mite as argetipe as 'n dinamiese proses getipeer word, sodat albei as 'n "working proposition" (Gould, 1981:44) beskou kan word. Die feit dat die waterslangsimbool nie net wyd verspreid in mitologiese stelsels voorkom nie, maar ook steeds binne nuwe historiese kontekste verder ontgin word (byvoorbeeld tans in die Afrikaanse prosa), bevestig die "oopheid" en dinamiek van die argetipe.

'n Verdere aanduiding van die argetipe as dinamiese konsep, spesifiek met waterslangsimboliek as voorbeeld, is naamlik die voorkoms van 'n groot hoeveelheid aanverwante verskynsels. Hier word volstaan met enkele voorbeelde; mitologiese assosiasies rondom "water" en "slang" skyn eindeloos te wees. Ansie Hoff (1995:40) wys daarop dat daar drie soorte Grootslange is wat as natuurmagte ' $n$ besonder belangrike rol speel in die wêreldbeskouing van die Khoekhoen, naamlik die waterslang, die veldslang en die dassie-adder. In sy boek Waar die volk skep (1994:35) plaas Pieter Grobbelaar 'n tekening van 'n dassie-adder met 'n kroon op sy kop, wat assosiasies oproep met die steen op die voorkop van die waterslang. Dan is daar ook nog vele ander verwante verskynsels, byvoorbeeld die misterieuse reëndier van die Boesmans $^{3}$, die basilisk, die waterbobbejaan en -perd, en die tokkelossie. Ander Suider-Afrikaanse waterslange, uit onder meer die Sotho-, Xhosa- en Zoeloe-kultuur, kan tot die argetipiese simboliek toegevoeg word, insluitende allerlei verbande met waterslange van die Kavango, Zaïre en Angola. Die simboliek kan voorts uitgebrei word om kosmiese waterslange in te sluit, waaronder Tiamat, Ourobouros en die Bybelse Leviatan as enkele voorbeelde. Waterslange en verwante argetipiese simbole kan as tekens beskou word, wat voortdurend assosiasies met ander tekens kan oproep, eerder as afsonderlike entiteite wat onafhanklik van mekaar bestaan. Spesifiek met betrekking tot vergelykende literatuurstudie het

3 Die term "Boesman" word gebruik met inagneming van moontlike negatiewe konnotasies. Met die benaming "San" blyk daar soortgelyke probleme te wees. Ek sluit aan by Helize van Vuuren en ander, wat die term "Boesman" gebruik, onder meer met die doel om die woord te neutraliseer en uiteindelik van sy negatiewe konnotasies te suiwer (Van Vuuren, 1995:25). 
hierdie meer dinamiese duiding van die argetipe verreikende implikasies wat allerlei nuwe moontlikhede open.

Die skrywer wat dit op hom of haar neem om die waterslangsimbool opnuut in nuwe kontekste te aktiveer, word gekonfronteer met 'n verskeidenheid mitologiese tradisies. Die uitdaging wat die mitiese intensie inhou, is naamlik of daarin geslaag kan word om die balans tussen die "nuwe" verhaal - dikwels vol eiesoortige assosiasies - en die tradisionele, histories bepaalde simboliek te handhaaf. Een van die mees volgehoue en geslaagde ontginnings van die waterslangsimboliek in Afrikaans kom voor in die kortverhaalbundel Die donker melk van daeraad (1994) deur George Weideman. Naas die waterslang verwys Weideman na soortgelyke verskynsels uit die Egiptiese, Skandinawiese en Hongaarse mitologieë, asook 'n verskeidenheid Europese volksprokies. Afgesien van die basilisk en die dassie-adder, figureer ook nog die horingsman, bomeester en sogenaamde Eenoog uit die Afrikaanse leefwêreld. Die vraag ontstaan wel of daar nie afbreuk gedoen word aan die numineuse dimensies van hierdie ryk bundel as gevolg van die groot hoeveelheid assosiasies en parallelle wat rondom die waterslang en sy wonderbaarlike steen opgeroep word nie. Die donker melk van daeraad is die sentrale teks van bespreking in die tweede artikel oor mitisiteit.

\subsection{Mitisiteit, geskiedenis en ideologie}

Vir Eric Gould veronderstel die mitiese intensie of ingesteldheid nie soseer die bybring van historiese kontekste nie, want dit gaan volgens hom by die funksionering van mitisiteit nie om die ondersoek na die oorspronge of ontwikkeling van bepaalde mitologiese motiewe nie. Hoewel die historiese dimensie van mitisiteit in hierdie ondersoek ook nie in die eerste instansie in terme van die oorsprong van spesifieke motiewe gedui word nie - in die sin van 'n definitiewe begin (byvoorbeeld 'n "basisverhaal" oor die waterslang) - word die historiese konteks waarbinne die mitiese teks funksioneer, van besondere belang geag.

Die intensie tot die peiling van die numineuse hang in 'n groot mate saam met die historiese konteks van waaruit die skrywer skryf. Daarom is dit grootliks ter sake dat as 'n skrywer oor die waterslang skryf, die bepaalde konteks waaruit die slang voortkom, in ag geneem sal word. Die klemverskil ten opsigte van Gould se beskouings kan saamgevat word in die onderskeid tussen "mities" en "mitologies". In aansluiting by Gould is die primêre uitgangspunt die vasstelling van die mitiese of numineuse dimensies van die ver- 
halende teks. Met die bybring van die historiese konteks word die "mitiese" uitgebrei om ook die "mitologiese" te omvat, dit wil sê die funksionering van 'n spesifieke mitologiese simbool (soos die waterslang) binne spesifieke historiese kontekste (die Suider-Afrikaanse konteks met byvoorbeeld die onderlinge kontak tussen Khoesaan en Westerling). Die ondersoek na die "mitologiese", wat die nagaan van oorspronge en allerlei assosiasies kan insluit, word egter ondergeskik gestel aan die mitiese intensie.

Die implikasie van hierdie onderskeid is dat die resultate van 'n ondersoek na mitisiteit op ten minste twee vlakke na vore kan tree. Op die meer inhoudelike vlak van 'n simbool soos die waterslang, word die mitiese relevansie daarvan binne 'n spesifieke historiese konteks, byvoorbeeld Suider-Afrika, ondersoek. Vanuit die meer teoretiese en metodologiese oorwegings gaan dit om die waarde van mitisiteit oor die algemeen, ongeag watter spesifieke simbool ondersoek word. Hierdeur word die basis van die vergelyking van tekste verbreed, deurdat mitiese tekste onderling vergelyk kan word sonder dat hulle noodwendig oor eensoortige mitologiese simboliek hoef te handel.

Hoewel Gould by sy tekstuele toepassings van die mitisiteitsbegrip nie soseer op die historiese inhoud van bepaalde simbole konsentreer nie, maak hy vanuit 'n teoretiese oogpunt wel voorsiening vir die bybring van kwessies vanuit breër histories-kulturele kontekste. Vir hierdie doel sluit hy aan by die beskouings van onder andere Jacques Lacan en Roland Barthes. Op die basis van Lacan se teorieë oor die onbewuste, wat naamlik op dieselfde wyse as taal gestruktureer sou wees, lê Gould verbande tussen die onbewuste en sy basiese uitgangspunt van die gaping tussen gebeurtenis en betekenis. Die verband tussen language en desire waaroor Lacan uitvoerig geskryf het, het volgens Gould (1981:73-74) in die eerste instansie met hierdie gaping of lack te make. Die wil of intensie tot betekenisgewing spruit primêr voort uit die menslike onbewuste, vanweë primordiale "aanvoelinge" van die spanning tussen taal en begeerte.

Lacan wys daarop dat die subjek, in die proses om sigself te leer ken, eers geobjektiveer moet word - 'n proses waarvoor die "Ander" nodig is (vgl. Gould, 1981:78). Op grond van die basiese verhouding tussen die subjek en die Ander, kan die Ander in die eerste instansie as die onbewuste aangedui word (vgl. Wilden, 1968:262). Die Ander speel as onbewuste ' $n$ bepalende rol in die subjek se omgaan met sy eie, "bewuste" self. Primêr as gevolg van die spesifieke wyse waarop taal gestruktureer is en funksioneer, naamlik in eerste 
instansie as "afwesige" betekenis, soek die subjek sigself via die taal by die Ander, wat voorts ook ander vorme kan aanneem as net die bewuste of onbewuste "self" (Wilden, 1968:264).

Juis ten opsigte van hierdie manifestasies van die onbewuste word die geskiedenis belangrik (Lacan, 1968:21). Gould (1981:75) vat hierdie verband tussen die onbewuste en 'n geskiedenis soos volg saam: "Insofar as the unconscious can be understood at all, it must have a history, and Lacan notes that the unconscious is the history of the subject." Met spesifieke verwysing na die argetipe, brei Gould (1981:31) hierop uit: "Since understanding is always a matter of interpretation, it follows that the archetype must be interpretable to exist at all; that is, it must have a discernible presence, a context, a history." Die onbewuste, as "Ander", neem dus 'n verskeidenheid gestaltes binne die konteks van die geskiedenis aan.

Mitisiteit het in die eerste plek te make met die verhouding tussen mite en literatuur. Albei hierdie terreine het op hul beurt weer met die geskiedenis te make. Douglas Davies (1994:1) formuleer dié verbande in heel algemene terme: "Myth and history reflect a characteristic search for meaning which is typically human and which, in life at large, takes many forms from science to poetry." Ook die skryf en lees van Afrikaanse waterslangverhale kan in die eerste plek as 'n search for meaning beskou word. Vir Gould is die ooreenkoms tussen mite, literatuur en geskiedskrywing geleë in die bewuste, intensionele soeke na betekenis. Vanweë hierdie bewuste intensie kan al drie diskoerse as voorbeelde van 'n "second-order system" (Gould, 1981:92) of gekodifiseerde stelsel getipeer word.

Dit is veral hierdie metatalige element wat dit moontlik maak om die werklikheid nie as "feit" nie, maar as gekodifiseerde stelsel te benader (Gould, 1981:107). Dit is terselfdertyd hierdie nie-feitelike element wat daartoe lei dat sowel mite as verhaal tot 'n "valse waarheid" of ideologie4 gedegradeer kan word. Die noue verwantskap tussen narratiwiteit en ideologie word deur Thompson (1984:198) soos volg saamgevat: "Ideology, in so far as it seeks to sustain relations of domination by representing them as legitimate,

$4 \quad$ Hier word die negatiewe konnotasie van die ideologie-begrip uitgelig, maar twee hoofbenaderings kan onderskei word. Volgens die deskriptiewe of "neutrale" benadering word ideologie omskryf as 'n versameling van idees ("beliefs"), houdings en gebruike wat by enige groep mense voorkom. Ideologie in negatiewe sin verwys na 'n vaste stel idees of beginsels waarvolgens die belange van bepaalde groepe mense beskerm en uitgebou word ten koste van ander (vgl. Geuss, 1981; ook Thompson, 1984). 
tends to assume a narrative form". Tipiese Afrikaner-mites, soos wat byvoorbeeld rondom die Groot Trek en Bloedrivier ontstaan het, is voorbeelde van sodanige ideologiserings. Ook waterslangverhale kan in diens van 'n bepaalde ideologie aangewend word, afhangende van die bewuste of onbewuste intensies van die skrywer.

In sy beskouings oor die verhouding tussen mite, ideologie en literatuur sluit Gould (1981:116 e.v.) aan by die sienings van Roland Barthes. Barthes is in die eerste plek nie besonder verdraagsaam ten opsigte van die mite nie, aangesien dit volgens hom 'n valse bewussyn by die meerderheid mense skep. Die waarde van Barthes se mite-beskouing lê egter daarin dat hy dit ontmasker as 'n produk van kultureel- en histories-bepaalde situasies; met ander woorde nie as 'n idee of "waarheid" verhewe bo historiese kontekste nie.

Juis die historisiteit van die mite het positiewe implikasies vir die literêre verwerking daarvan. As histories-bepaalde betekenisproses laat die mite altyd moontlikhede oop vir die vorming van verdere betekenis (vgl. Gould, 1981:119). Die dinamiese proses van aanpassing en transformasie van sowel die mite as die argetipiese simbool - veral as literêre verskynsels binne historiese kontekste vorm die basis van mitisiteit. Juis wanneer die mite en argetipe as voortdurend transformerende working proposition verstaan word, kan die bybring van 'n spesifieke historiese konteks hierdie werking des te duideliker illustreer. Met ander woorde: die voortdurende aanpassing van byvoorbeeld die waterslang as argetipiese simbool word die beste geillustreer binne bepaalde sosiokulturele kontekste.

\subsection{Die mitiese interpretasieproses: metafoor en metonimie, simboliek en allegorie}

Hoe gebeur dit nou konkreet binne die voortgesette interpretasieproses dat sekere simbole hul argetipiese eienskappe binne die konteks van 'n literêre teks behou? Gould (1981:189) gebruik die frase "human compromise" vir die soort betekenisgewing wat plaasvind ten opsigte van die "vreemde", irreële gebeure wat dikwels in mitologiese verhale voorkom. Mede vanweë die basiese gaping tussen meaning en event vind daar geen letterlike identifikasie plaas nie. Die metafoor kan volgens Gould (1981:46) as die belangrikste verklaringsprinsipe vir hierdie soort interpretasiemeganismes beskou word: "There is some logic to the metaphor, some interchangeability between the outside fact (mythology itself) and the inside (my knowledge of human nature) which allows me to interpret the tale." 
In sy behandeling van die metafoor gee Gould 'n uitvoerige samevatting van die sienings van Paul Ricoeur, waarvan slegs die relevansie vir die mite en die argetipe hier aangedui word. Ricoeur se beskouings berus op 'n poging tot 'n sintese tussen metaforiese en metonimiese prosesse in taalgebruik. Die noue samehang tussen metafoor en metonimie kan soos volg saamgevat word (Gould, 1981:53):

If there is a predicative ideal, then it is not endless play, but play-for-substitution, a process in which metaphor aspires to the status of metonymy. Interpretation must acknowledge the free play of language, but it is always interpretation-for: reading and writing in the pursuit of accurate significance.

Die relevansie vir die mite en argetipe is soos volg (Gould, 1981:53):

It would seem that we may yearn to be absorbed by the archetype as primordial symbol, but all that language will ever let us find is the absent metonymy in the metaphor. We cannot substitute a literal meaning for the figurative ..., for if all language is metonymy/metaphor, then it is never literal: only metaphor, or at best metonymy, can interpret a metaphor.

Metonimie gee die "ketting" van interpretasiemoontlikhede, die voortdurende proses van semiotiese betekening. Daarteenoor - of in paradoksale samehang daarmee - vervang die metafoor tydelik die metonimiese teken en bring 'n soort semantiese "konstantheid" danksy die menslike wil en intensie tot interpretasie. Die waterslang kan as voorbeeld geneem word. Te midde van die eindelose prosesse van semiotiek en metonimie (die oneindige hoeveelheid waterslange en verwante verskynsels, met hul ewe oneindige reekse eienskappe) verkry die "Waterslang van die Oranjerivier", as spesifieke simbool binne 'n bepaalde konteks (Suider-Afrika), 'n voorlopige "konstante" betekenis (die metafoor van die semantiese fase). Die voortdurende wisselwerking tussen metafoor en metonimie lei verder daartoe dat daar gedink moet word in terme van "grade" of "vlakke" van konstantheid binne die interpretasieproses. Die Suider-Afrikaanse konteks, met al die verskillende assosiasies rondom waterslange en wat dit inhou, vorm weer die metonimiese kader waarbinne waterslange en verwante verskynsels binne 'n bepaalde literêre werk (byvoorbeeld George Weideman se Die donker melk van daeraad) voorlopige metaforiese konstantheid verkry - totdat dié werk weer geïnterpreteer en die metonimiese proses voortgesit word. Dit is om hierdie rede dat Gould (1981:68-9) van mening is dat spesifiek die argetipe by die voortdurende 
herinterpretasie van mitologiese motiewe - mitisiteit, met ander woorde - steeds so 'n belangrike rol speel.

Mitisiteit kom nie net tot uitdrukking in die voortdurende wisselwerking tussen metafoor en metonimie nie. Die metafoor word dikwels uitgebrei tot allegorie. In die meeste verhale met 'n mitologiese strekking is daar die doelbewuste intensie om die numineuse te peil. Gould (1981:261) praat van hierdie intensie as 'n "allegory of intent". Die bewuste intensie om deur middel van 'n mitiese ingesteldheid die numineuse te benader, is terselfdertyd die intensie wat aanleiding gee tot die allegorie (Gould, 1981:209): "The recovery of the numinous ... has something to do with a union of ordinary writing and extraordinary vision." Die roman Rooigrond (1995) deur Thomas Deacon is een van die beste voorbeelde van 'n mitiese teks in Afrikaans, waar die allegoriese beeld van die lewe as 'n pad, deurlopend in die verhaal volgehou word. Die waterslang is een van baie gevare wat die hoofkarakter, Alfred Mokgotsi, op sy lewenspad moet trotseer.

Argetipes kom voort uit die onbewuste. Deur middel van metafoor, simbool en allegorie, weliswaar as talige prosesse, word 'n weg gevind om hulle enigsins op bewuste wyse gestalte te laat kry. Hiervolgens kan die argetipe gesien word as "interface" of "contact surface" (vgl. Gould, 1981:63) na die bewuste toe. Dit is die belangrike interpretatiewe funksie van sowel skrywer as leser om hierdie kontak tussen onbewuste en bewuste prosesse te bewerkstellig, en sodoende "ou" mites opnuut relevant te maak.

\section{Kriteria vir die funksionering van mitisiteit in vergelykende literatuurstudie}

In die voorafgaande paragrawe is argumente aangevoer ter motivering van die fyn balans tussen narratiewe en numineuse dimensies, as een van die belangrikste kriteria vir mitisiteit. Die verskraling van mitisiteit tree in wanneer die narratiewe dimensies om een of ander rede oorheersend word, iets wat gewoonlik op twee hoofmaniere geskied. Eerstens kan dit gebeur dat die vertelproses as sodanig 'n doel in sigself word, byvoorbeeld deur oormatige metonimiese assosiëring rondom 'n bepaalde simbool. Die historiese konteks word dan gewoonlik nie voldoende in ag geneem nie.

Jung (1964:90) self kan in hierdie verband aangehaal word: 
When their numinosity (i.e. die argetipes s'n - JL) has ... been banished, the process of limitless substitution begins - in other words, one glides easily from archetype to archetype, with everything meaning everything.

Argetipiese simbole kan dus op 'n té oop wyse gehanteer word, met die gevolglike verlies aan numinositeit. Wanneer 'n skrywer byvoorbeeld op willekeurige wyse allerlei nuwe assosiasies rondom waterslangsimboliek uit eie verbeelding oproep, of wanneer die waterslang op ongemotiveerde wyse met 'n groot hoeveelheid aanverwante verskynsels (soos die reënbul, tokkelossie of waterbobbejaan) geskakel word, dan tree die numineuse werking van mitisiteit gewoonlik op die agtergrond en word die balans tussen die narratiewe en die numineuse versteur. André P. Brink se Die eerste lewe van Adamastor (1988) kan dien as voorbeeldteks. Die skrywer se verbeelding gaan te ver uit bo die historiese konteks van die Khoesaan-waterslangsimboliek, wat 'n deurlopende stramien van die verhaal vorm.

Wydlopige assosiëring, as oorsaak van verminderde mitisiteit, hoef nie net deur die skrywer in sy herinterpretasie van mitologiese motiewe gedoen te word nie. Ook die wyse waarop die leser 'n verhaal interpreteer, kan daartoe lei dat die potensiële mitisiteit van 'n teks nie tot sy reg kom nie. Die leser of kritikus kan so meegevoer word deur die mitologiese verwysings in 'n verhaal dat die mitiese intensies van die skrywer nie raakgesien word nie. In die Afrikaanse letterkunde kan die soort aandag wat Etienne Leroux ontvang het, as voorbeeld dien. Kannemeyer (1983:347) skryf in hierdie verband:

Sy (dit is Leroux s'n - JL) besondere wêreld (verlei) ondersoekers dikwels tot die blote 'ontsyfering' van die Jungiaanse en ander verwysingsvelde, die 'los' of lukraak gebruik van J.E. Cirlot se Dictionary of Symbols, die belasting met 'n nie-literêre terminologie en die verwaarlosing van wesentlike struktuuraspekte van die romans as sodanig.

Afgesien van die strukturele aspekte, kan bygevoeg word dat die sosiaal-politieke relevansie van Leroux se werk ook dikwels geïgnoreer is, wat weer op hul beurt verband hou met die historiese dimensies van mitisiteit.

In die tweede plek vind die teenoorgestelde proses van verskraling plaas wanneer die metaforiese werking van die argetipiese simbool oormatig beklemtoon word, met ander woorde wanneer die betekenis daarvan in so 'n mate gefikseer word dat die dinamiese werking van die "oop" argetipe teengegaan word. In dergelike 
gevalle word die belang van die historiese konteks weer oorbeklemtoon. Dit gebeur gewoonlik wanneer die mitiese dimensies van 'n verhaal in diens gestel word van ideologiese of moralistiese doelstellings. Die oormatige fiksering van die argetipiese simbool beteken terselfdertyd die einde van sy mitiese funksionering. Hierdeur verloor die argetipe en sy simboliese manifestasies hul dinamiese aard as working propositions.

Twee voorbeelde uit die Afrikaanse prosa van waar moralistiese oorweginge mitisiteit teenwerk, is die 1917-roman Jakob Platjie deur G.R. von Wielligh en die meer onlangse Meraai van Rolbos (1989) deur Charlotte de Beer. In albei romans word 'n spanning tussen enersyds die tradisionele godsdiens van die Griekwas en andersyds die Christendom voorgehou. Wanneer albei die hoofkarakters op vry ongemotiveerde wyse ' $n$ definitiewe en finale keuse vir Christelikheid doen, dan word die numineuse vraagstelling, as belangrike voorwaarde vir mitisiteit, in die gedrang gebring.

Die vrymakende oorskryding van ideologie en moralisme deur middel van mitisiteit geskied volgens Gould (1981:123-4) in die eerste plek aan die hand van ironiseringsprosesse. Pogings om die realiteit tot "feit" te verklaar en op dié wyse die gaping tussen meaning en event te oorkom, word voortdurend geïroniseer, nie net deur die "werklikheid" self nie, maar veral ook deur middel van talige prosesse as sodanig. Die paradoks wat hiermee gepaardgaan, is dat juis dié gaping die mens voortdurend dwing tot nuwe pogings om dit te oorkom. Ironisering vra steeds om nuwe verklaringsmeganismes, nuwe maniere om die numineuse of die onverklaarbare te peil. Dit gee aanleiding tot nuwe stories of verhale, veral dié met 'n mitiese ingesteldheid. Gould (1981:252) sien die mitiese kunsuiting as event, in direkte relasie tot die numineuse: "But art only authenticates the numinous insofar as it reveals that illumination is lived through - even as writing - as well as being a visionary event: a moment for the reader and writer to progress toward." Deur middel van die prosesse van metafoor, simbool en allegorie, as voorlopige momente van "closure to interpretation" (Gould, 1981:56), hoef die paradoksale en ironiese werking van taal nie aanleiding te gee tot volslae pessimisme en sinisme nie, maar word nuwe betekenismoontlikhede voortdurend geopen.

\section{Afsluiting}

'n Sentrale vraag wat in die Inleiding aan die orde gestel is, is naamlik of die herlewing van "primitiewe" verskynsels soos die waterslang as inherente deel van postmodernistiese tendense in die 
hedendaagse letterkunde beskou kan word. Of moet resente waterslangverhale in Afrikaans, byvoorbeeld dié van Brink, Weideman en ander waarna kortliks verwys is, bloot getipeer word as "herinneringsliteratuur" of "kontreikuns", buite die hoofstroom van moderne ontwikkelinge? Daar is 'n saak daarvoor uitgemaak dat die voortgesette interpretasie van die waterslangsimbool gewaarborg word deur die mitiese werkinge daarvan, met sy argetipiese oorspronge in die menslike onbewuste. Maar speel die mite nog enigsins 'n rol binne postmodernistiese ingesteldhede?

In 'n versamelbundel Myth and the Making of Modernity. The Problem of Grounding in Early Twentieth-Century Literature (Bell \& Poellner, 1998) motiveer een van die redakteurs, Michael Bell, waarom die mite in moderne verhaalvorm steeds ' $n$ belangrike rol kan speel, in 'n wêreld wat hy tipeer as "post-religious, even postmetaphysical" (Bell \& Poellner, 1998:1). Die krisis van moderniteit, wat die aflegging van metafisiese waardes inhou, het tot gevolg dat die mite nuwe relevansie en betekenis kry, wat veel meer omvat as blote nostalgie vir die pre-moderne fases van die menslike bestaan.

Dit gaan vir Bell en Poellner (1998:2) om die "sense of a philosophical responsibility", wat ook as "conviction" beskou kan word:

Whereas primary, or archaic, myth, is lived as belief, or reality, the self-conscious, modern use of myth focuses an awareness of living as conviction, which is the only way it can be lived, a world of values which cannot be grounded in anything beyond itself.

Wat Bell as conviction aandui, kan direk in verband gebring word met die mitiese intensie of visie van die skrywer. Religieuse tradisies, in die sin van bepaalde godsdienste, kan agtergelaat word, maar religiositeit of numinositeit, as 'n bepaalde ingesteldheid ten opsigte van die werklikheid, bly funksioneer as universele menslike eienskap - ook in postmodernistiese konteks. Religiositeit sal op verskillende wyses gedefinieer kan word, maar dát dit bestaan, met oorspronge in die menslike onbewuste, is 'n basiese uitgangspunt ten grondslag aan die verstaan van die funksionering van mitisiteit.

Mitisiteit verwys nie in die eerste plek na 'n bepaalde fase in die menslike geskiedenis nie, maar eerder na 'n "structure of consciousness" (Baring \& Cashford, 1993:8), of voorwaarde vir mitiese denke en belewing. Daarom kan literêre tekste met mitiese intensies soos dié van Weideman - wat binne postmodernistiese konteks ontstaan, inderdaad teruggryp na die oudste verteltradisies van 'n 
verre verlede, terwyl dit terselfdertyd probeer om 'n toekomsvisie vir die 21ste eeu te verwoord.

Omdat dit gaan om 'n bewuste intensie of visie as algemene voorwaarde vir mitisiteit, kan hierdie visie (of conviction) van mitiese tekste uit byvoorbeeld die Afrikaanse letterkunde, gedeel word met mitiese tekste uit letterkundes van ander tale. Uit die tekstuele voorbeelde, waarna slegs kortliks in die onderskeie onderafdelings verwys is, maar waarop uitvoeriger in die tweede artikel oor die toepassing van die mitisiteitsbegrip ingegaan sal word, blyk die moontlikhede wat mitisiteit vir die vergelyking van literêre tekste bied. Terselfdertyd bied dit ook 'n basis vir evaluering, met die wisselwerking tussen narratiewe en numineuse dimensies as hoofkriterium, wat weer nou saamhang met die balans tussen metonimiese assosiëring en metaforiese fiksering. Wanneer tekste tot op groot hoogte met dieselfde mitologiese gegewe omgaan, byvoorbeeld waterslangsimboliek, is die kritiese evaluering in 'n sekere sin makliker as wanneer dit gaan om 'n vergelyking met simbole uit ander kontekste, byvoorbeeld die Nederlandse of Engelse literatuur. Indien literatore wel kan ooreenkom oor 'n gemeenskaplike konsep van mitisiteit ondanks uiteenlopende simboliese verskynsels, behoort dit in prinsipe wel moontlik te wees om mitiese tekste vanuit diverse kontekste te vergelyk en te evalueer.

Dit is nie 'n kwessie van 'n teks wat óf mities is óf juis nie. Daar is eerder sprake van grade van mitisiteit, met die een skrywer wat in 'n groter mate daarin slaag om die potensiële mitiese kwaliteit van 'n bepaalde simbool binne 'n verhaal te ontgin as wat met ' $n$ ander verhaal die geval is. Die kwessie van potensiële mitisiteit hou wel in dat verwysings na ' $n$ bepaalde mitologiese simbool nog geen voorwaarde vir mitisiteit is nie. In 'n "ware" mitiese teks word die verwerking van die mitologiese simbool steeds ondergeskik gestel aan die mitiese intensie. Die mitologiese motief - soos die waterslang - hou in die eerste plek verband met die plasing van 'n bepaalde simbool in 'n historiese konteks; die "mitiese" hou primêr verband met die numineuse intensie, wat bepaalde historiese kontekste juis kan oorskry. So word mitisiteit die basis vir indringende vergelykende literatuurstudie en interkulturele diskussie.

Die basis vir mitisiteit - die numineuse vraagstelling - is steeds die spanning wat daar tussen die betekenaar en die betekende bestaan; of om Gould vir 'n laaste keer aan te haal: die gaping tussen "meaning" en "event". Dit is hierdie gaping wat die mens se bestaan 'n ironiese en paradoksale aangeleentheid maak. Dit is as gevolg van taal dat die gaping ontstaan; die mens beskik oor weinig meer 
as taal om die gaping te probeer oorbrug. Sy intensie om dit te doen, sal daarom altyd 'n geïroniseerde intensie bly. Die ironie waarborg die vryheid om steeds te wil probeer. Hierin lê ook die humor - die lagwekkende - van die menslike bestaan. Die vraag na die numineuse, veral deur middel van stories, en die humor en die ironie wat daarmee saamgaan: dit is die kern van mitisiteit.

Fyner nuanses van mitiese simboliek, soos humor en ironie, kom eers tot hul reg in die deeglike interpretasie van 'n spesifieke verhaal. In die tweede artikel, "Waterslangverhale in Afrikaans: die relevansie van mitisiteit", word in die eerste plek gekyk na geslaagde voorbeelde van mitisiteit. Daar sal ook nagegaan word waarom in sekere waterslangverhale, met 'n definitiewe potensiaal tot mitisiteit, dié moontlikhede nie volledig ontgin is nie. Dit is ook 'n spesifieke teks, binne 'n spesifieke historiese realiteit, wat die vraag oproep of daar nie ook ander vorme van mitisiteit bestaan as dié wat berus op die wisselwerking tussen narratiewe en numineuse dimensies nie. Soos wat die argetipiese simbool sigself kontinueer, so word die kritiese gesprek oor mitisiteit voortgesit.

\section{Geraadpleegde bronne}

Bell, M. \& Poellner, P. (eds.) 1998. Myth and the making of modernity. The problem of grounding in early twentieth-century literature. Amsterdam : Rodopi.

Brink, A.P. 1988. Die eerste lewe van Adamastor. Kaapstad: Saayman \& Weber.

Davies, D. 1994. Introduction: raising the issues. In: Holm, J. \& Bowker, J. (eds.) Myth and history. London: Pinter. pp. 1-7.

Deacon, T. 1995. Rooigrond. Kaapstad : Tafelberg.

De Beer, C. 1989. Meraai van Rolbos. Pretoria : Van der Walt.

Dégh, L. 1977. Biologie des Erzählguts. In: Ranke, K. (red.) Enzyklopädie des Märchens. Handwörterbuch zur historischen und vergleichenden Erzählforschung. Band 2. pp. 386-405.

Geuss, R. 1981. The idea of a critical theory. Habermas \& the Frankfurt School. Cambridge : Cambridge University Press.

Gould, E. 1981. Mythical intentions in modern literature. Princeton : Princeton University Press.

Grobbelaar, P.W. (red.) 1994. Abel Coetzee en sy rubriek 'Waar die volk skep'. Vroeë Afrikaanse volkskultuur. Stellenbosch : Genootskap vir Afrikaanse Volkskunde.

HAT

kyk Odendal, F.F. (red.) 1984.

Hoff, A. 1995. Puberteitsrite van 'n Khoekhoemeisie. South African Journal of Ethnology, 18(1):29-41.

Jung, C.G. (ed.) 1964. Man and his symbols. New York : Laurel.

Kannemeyer, 1983. Geskiedenis van die Afrikaanse literatuur. Vol. 2. Kaapstad: Academica. 
Krüger, J.S. 1995. Along edges. Religion in South Africa: Bushman, Christian, Buddhist. Pretoria : University of South Africa.

Lacan, J. 1968. The language of the Self. The function of language in psychoanalysis. Translated with notes and commentary by Anthony Wilden. Baltimore : The Johns Hopkins Press.

Lombard, J. 1999. Waterslangverhale in en rondom Afrikaans: 'n ondersoek na mitisiteit as basis vir vergelykende literatuurstudie. Potchefstroom : PU vir CHO. (Proefskrif - Ph.D.)

Lewis-Williams, D. \& Dowson, T.A. 1989. Images of power. Understanding Bushman rock art. Johannesburg : Southern Book Publishers.

McFague, S. 1982. Metaphorical theology. Models of God in religious language. London : SCM.

Odendal, F.F. (red.) 1984. Verklarende handwoordeboek van die Afrikaanse taal. Johannesburg : Perskor.

Segal, R.A. 1984. Joseph Campbell's theory of myth. In: Dundes, A. (ed.) Sacred narrative. Readings in the theory of myth. Berkeley : University of California Press. pp. 256-269.

Schmidt, S. 1982. Ou optekeninge van Europese volksvertellings by die Namas en Damaras in Suidwes-Afrika. Tydskrif vir Volkskunde en Volkstaal, 38(3):1-19.

Thompson, J.B. 1984. Studies in the theory of ideology. Cambridge : Polity Press.

Van Vuuren, H. 1995. Die mondelinge tradisie van die /Xan en 'n herlees van Von Wielligh se Boesman-Stories. Tydskrif vir Letterkunde, 33(1):25-35, Feb.

Von Wielligh, G.R. 1922 [1917]. Jakob Platjie. Egte karaktersketse uit die volkslewe van Hotnots, Korannas en Boesmans. Pretoria : De Bussy.

Weideman, G.H. 1994. Die donker melk van daeraad. Kaapstad : Tafelberg.

Wilden, A. 1968. Lacan and the Discourse of the Other. In: Lacan, J. The language of the Self. The function of language in psychoanalysis. Translated with notes and commentary by Anthony Wilden. Baltimore : The Johns Hopkins Press. pp. 157-311.

\section{Kernbegrippe:}

argetipe

mitisiteit

numinositeit

vergelykende literatuurstudie

waterslangsimboliek

\section{Key concepts:}

archetype

comparative literature

mythicity

numinosity

water snake symbolism 